\title{
Kudoa inornata sp. n. (Myxosporea: Multivalvulida) from the skeletal muscles of Cynoscion nebulosus (Teleostei: Sciaenidae)
}

\author{
Iva Dyková ${ }^{1}$, Isaure de Buron ${ }^{2}$, Ivan Fiala $^{1}$ and William A. Roumillat ${ }^{3}$ \\ ${ }^{1}$ Institute of Parasitology, Biology Centre of the Academy of Sciences of the Czech Republic, Branišovská 31, 37005 České \\ Budějovice, Czech Republic; \\ ${ }^{2}$ Department of Biology, College of Charleston, 58 Coming St., Charleston, South Carolina 29401, USA; \\ ${ }^{3}$ Marine Resources Division, Inshore Fisheries Section, South Carolina Department of Natural Resources, 217 Ft. Johnson Road, \\ Charleston, South Carolina 29412, USA
}

\begin{abstract}
A new myxosporean species, Kudoa inornata sp. n. (Myxosporea: Multivalvulida), is described from skeletal muscles of the spotted seatrout Cynoscion nebulosus (Cuvier), collected in estuarine waters along the coast of South Carolina, USA. Light microscopic and ultrastructural characters rank this species to the group of Kudoa species with simple-shaped spores. The uniqueness of the SSU and LSU rDNA sequences justifies its status of a new species with sister relationship to Kudoa paniformis. The $100 \%$ prevalence in seatrout from four out of five localities sampled and pathogenicity of $K$. inornata recognized in this study should motivate further screening for infections in its host, which is considered a commercially important game fish with a wide distribution in the Western North Atlantic.
\end{abstract}

Key words: Myxozoa, Myxosporea, Kudoa inornata, muscle infections, Cynoscion nebulosus

The spotted seatrout Cynoscion nebulosus (Cuvier) (Sciaenidae) distributed along the coasts of the Western North Atlantic and through the Gulf of Mexico is considered one of the most important fish species in this area (Bortone 2003). In the southeast, recreational catches of this species average almost 7 million fish per year (Berger 2008). Due to this fact, spotted seatrout was included among indicators of biological integrity of coastal resources (South Carolina Estuarine and Coastal Assessment Program, SCECAP) and numerous studies concern its biology and management (Bortone 2003, James et al. 2007).

In addition to several parasitic metazoans, only two myxosporean species have been reported from C. nebulosus: Henneguya sp. from the dorsal and caudal fins (Overstreet 1978, 1983) and Myxidium sp. from the gallbladder (Blaylock and Overstreet 2003). Among myxosporeans described from other sciaenid hosts, four nominal and one unidentified Kudoa species were reported. In addition to K. sciaenae Terán, Llicán et Luque, 1990 that was described from the skeletal muscles of Pacific Ocean Stellifer minor (Oliva et al. 1992), the other Kudoa species were described from the Gulf of Mexico sciaenids: K. branchiata Joy, 1972 from the gills and K. leiostomi Dyková, Lom et Overstreet, 1994 from the skeletal muscles of Leiostomus xanthurus (Joy 1972 and Dyková et al. 1994, respectively), and K. hypoepicardialis Blaylock, Bullard et Whipps, 2004 from the heart of Pogonias cromis (Blaylock et al. 2004). An unidentified Kudoa sp. was reported from the skeletal muscle tissue of Cynoscion arenarius (Overstreet 1983).

Although Kudoa species are reported commonly from diverse fish hosts in various parts of the Eastern Atlantic, comparatively few records relate to the Western Atlantic. In the coastal waters where $C$. nebulosus occurs, $K$. funduli (Hahn, 1915) was found in Fundulus heteroclitus (Hahn 1915, Meglitsch 1948, Akaishi et al. 2004), K. clupeidae (Hahn, 1917) was reported from several clupeids and an eelpout (Hahn 1917, Meglitsch 1947, 1948, Reimschuessel et al. 2003 and Nigrelli 1946, respectively) and K. cerebralis Paperna et Zwerner, 1974 from Morone saxatilis (Paperna and Zwerner 1974). A Kudoa sp. that differed from those species was reported from Morone americana and Brevoortia tyrannus (Bunton and Poynton 1991, Webb et al. 2005, respectively). Kudoa crumena Iversen et van Meter, 1967 was described from the Spanish mackerel Scomberomorus maculatus from the Atlantic coast of Florida and was reported also from Thunnus albacores in North Carolina (Iversen and Van Meter 1967, Moran et al. 1999, Kent et al. 2001). In addition to Kudoa spp. described from sciaenids mentioned above, K. shkae Dyková, Lom et Overstreet, 1994 and four unnamed species 
were reported from skeletal muscles of various brackish and marine fishes from the Gulf of Mexico (Overstreet 1983, Dyková et al. 1994), which is the southern-most part of the distribution range of Cynoscion nebulosus.

The considerable number of unnamed Kudoa species reported from various fish host species from all around the world can be attributed to the paucity of features distinguishing the morphology of spores. Because of the lack of distinguishing features, both molecular and morphological approach was taken to describe a Kudoa sp. found in the skeletal muscles of $C$. nebulosus. We believe this approach is an effective method to minimize ambiguity in species descriptions of myxozoans.

\section{MATERIALS AND METHODS}

A total of 23 spotted seatrout were collected in November and December, 2008 (using trammel netting and electro fishing) in five localities monitored for biological integrity by the South Carolina Department of Natural Resources: locality 1: Romain Harbor $\left(33^{\circ} 01^{\prime} 45^{\prime \prime} \mathrm{N}, 79^{\circ} 22^{\prime} 25^{\prime \prime} \mathrm{W}\right)$, salinity $32-35 \%$, 9 specimens, total length (TL) $400-450 \mathrm{~mm}$; locality 2: upper Ashley River $\left(32^{\circ} 53^{\prime} 0^{\prime \prime} \mathrm{N}, 80^{\circ} 04^{\prime} 50^{\prime \prime} \mathrm{W}\right)$, salinity $5 \%$, 1 specimen, TL $188 \mathrm{~mm}$; locality 3: Ashley River $\left(32^{\circ} 48^{\prime} 0^{\prime \prime} \mathrm{N}, 79^{\circ} 58^{\prime} 20^{\prime \prime} \mathrm{W}\right)$, salinity 22\%, 3 specimens, TL $300-450 \mathrm{~mm}$; locality 4: Combahee River that drains in the ACE basin $\left(32^{\circ} 38^{\prime} 32^{\prime \prime} \mathrm{N}, 80^{\circ} 40^{\prime} 29^{\prime \prime} \mathrm{W}\right)$, salinity 5.3\%o, 1 specimen, TL $163 \mathrm{~mm}$ and salinity 2.6\%, 1 specimen, TL $83 \mathrm{~mm}$; locality 5: ACE basin $\left(32^{\circ} 30^{\prime} 0^{\prime \prime} \mathrm{N}\right.$, $\left.80^{\circ} 26^{\prime} 18^{\prime \prime} \mathrm{W}\right)$, salinity $34-38 \%$, 8 specimens, TL $250-450 \mathrm{~mm}$.

Samples of epaxial myomeres were excised at the level of the dorsal fin of each spotted seatrout. Small pieces of fresh samples were squashed and examined under the light microscope. Samples of muscle tissue, together with samples of other organs, were fixed in Davidson fixative and processed for histology. $\mathrm{Ku}$ doa spores found in fresh or gradually decomposing samples of muscle tissue were concentrated by sedimentation and centrifugation for light microscopical and molecular studies. Spores were measured according to the method of Lom and Arthur (1989). Due to the absence of grossly visible lesions in the muscle tissue, Kudoa-positive samples could only be separated for electron microscopy from slightly squashed fresh muscle tissue. These were fixed in sucrose-sodium cacodylate-buffered $2 \%$ glutaraldehyde for $24 \mathrm{~h}$, stored in holding buffer for three weeks, postfixed in 1\% osmium tetroxide and embedded in Spurr resin (Harris 1991). Ultrathin sections were double stained with uranyl acetate and lead citrate and examined under a JEOL JEM1010 electron microscope at $80 \mathrm{kV}$ accelerating voltage.

DNA extraction, PCR, and cloning. Samples of muscle tissue stored for one week at $4{ }^{\circ} \mathrm{C}$ were homogenized in PBS. The homogenate was strained and myxospores were left to sediment in vials. Samples from three host individuals were treated separately. Prior to extraction of DNA, myxospores were crushed in beadbeater (FastPrep ${ }^{\mathbb{}}$-24, M.P. Biomedicals, CA, USA). DNA was extracted using the Jetquick Tissue DNA Spin Kit (Genomed, Germany) according to the manufacturer's protocol. The SSU rRNA gene was amplified using universal eukaryotic primers ERIB1 and ERIB10 (Barta et al. 1997). The LSU rDNA was assembled by two overlapping parts prepared by two nested PCRs. Briefly, the first part of LSU was obtained using the NLF160-NLR1694 and NLF184-NLR1270 primer sets, and the second part using the NLF1050-NLR3284 and NLFKudNLR3113 primer sets (Bartošová et al., in press). PCR was carried out in a $25 \mu \mathrm{l}$ volume using $10 \mathrm{pmol}$ of each primer, $250 \mu \mathrm{M}$ of each dNTP, $2.5 \mu$ of $10 \times$ PCR Buffer (Top-Bio, Czech Republic), and $1 \mathrm{U}$ of Taq-Purple polymerase (Top-Bio, Czech Republic). The PCR cycling parameters for the primary PCR of both SSU and LSU rDNA were $95^{\circ} \mathrm{C}$ for $3 \mathrm{~min}$, then 30 cycles of $95^{\circ} \mathrm{C}$ for $1 \mathrm{~min}, 48^{\circ} \mathrm{C}$ for $1 \mathrm{~min}, 72^{\circ} \mathrm{C}$ for $2 \mathrm{~min}$, followed by $10 \mathrm{~min}$ incubation at $72^{\circ} \mathrm{C}$. Amplification for the nested PCR of LSU rDNA consisted of $95^{\circ} \mathrm{C}$ for $3 \mathrm{~min}$, then 30 cycles of $95^{\circ} \mathrm{C}$ for $1 \mathrm{~min}, 52^{\circ} \mathrm{C}$ for $1 \mathrm{~min}, 72^{\circ} \mathrm{C}$ for $1 \mathrm{~min}$, followed by $10 \mathrm{~min}$ incubation at $72{ }^{\circ} \mathrm{C}$. PCR products were isolated from the $1 \%$ agarose gel using the Jetquick Gel Extraction Spin Kit (Genomed, Germany), ligated into pDrive Cloning vector (Qiagen PCR Cloning Kit, Germany) and transformed into competent E. colistrain XL-1. Clones were sequenced from both strands on an ABI PRISM 3130xl automatic sequencer (Applied Biosystems, Czech Republic).

Phylogenetic analysis. SSU and LSU rDNA sequences were aligned together with sequences of Kudoa spp. retrieved from GenBank. Accession numbers of sequences included in the study are given in Fig. 15. The SSU and LSU rDNA alignments were generated by the Clustal W algorithm implemented in Clustal X 1.83 (Thompson et al. 1997) with arbitrarily chosen parameters ( 8.0 for gap opening penalty and 6.0 for gap extension penalty). The alignments were manually edited using the program BioEdit 7.0.5.2 (Hall 1999).

Maximum parsimony (MP) analyses were performed in PAUP* 4.0 b10 (Swofford 2001) by heuristic search with random taxa addition (10 replications), the ACCTRAN-option, and the TBR swapping algorithm. Gaps were treated as missing data and Ts $/ \mathrm{Tv}$ ratio $=1: 2$. Branch supports were obtained by 1,000 bootstrap replicates with random sequence additions. For the maximum likelihood (ML) analyses, the likelihood ratio test (LRT) implemented in the Modeltest, version 3.06 (Posada and Crandall 1998) was used to determine the best model of evolution. ML was performed with the GTR $+\Gamma+\mathrm{I}$ model for SSU rDNA and combined SSU and LSU rDNA data, whereas GTR $+\Gamma$ model was applied for LSU rDNA data. Clade support was assessed with bootstrapping (500 bootstrap replicates). For combined SSU + LSU rDNA data, Bayesian inference (BI) was computed in MrBayes 3.1.2 (Ronquist and Huelsenbeck 2003). Likelihood parameters were set to $n s t=6$, rates $=$ invgamma, ngammacat $=4$ (equivalent to the $\mathrm{GTR}+\Gamma+\mathrm{I}$ model, as suggested by Modeltest). Posterior probabilities (PP) were estimated over 1,000,000 generations via two independent runs of four simultaneous MCMC chains with every 100th tree saved. Loglikelihood scores were plotted and the final $95 \%$ of trees were used to produce a majority rule consensus tree.

\section{RESULTS}

Light microscopy of squash preparations revealed the presence of Kudoa spores (Figs. 1-3) in the muscle tissue of 21 out of 23 (91\%) examined specimens of C. nebulosus. Histological examination revealed the same $91 \%$ prevalence of infection $(9 / 9,1 / 1,3 / 3,2 / 2$, and $8 / 8$ specimens positive/examined from localities $1,2,3$ and 5 , respectively; $2 / 2$ specimens negative from locality 4 ). Spores were observed in aggregates, the length of which 
reached 200-300 $\mu \mathrm{m}$. Although aggregates of spores localised between muscle fibres were observed in all specimens under study, histological examination showed that Kudoa spores developed inside the muscle fibres (Figs. 4-7). The extent of damage of muscle fibres was consistent with the progress in development of plasmodial stages (Figs. 4-7). The fate of infected muscle fibres, i.e., their possible complete replacement with mature spores was documented (Fig. 7, arrows). Mature spores that substituted sarcoplasm in the long segment of muscle fibre were enveloped by a thin layer of sarcolemma, which separated them from intermysium, suggesting an easy liberation of mature spores from the affected muscle fibres and invasion of intermysium, as often observed. Similarly as in other Kudoa spp. infections of fish skeletal muscles, the overall extent of damage important for the quality of flesh evidently depends on intensity of infection, i.e., the number of affected muscle fibres. Host reaction to developing plasmodial stages or aggregates of spores liberated from muscle fibres was not observed in specimens under study. Kudoa spores were observed exclusively in skeletal muscles.

\section{Kudoa inornata sp. $\mathrm{n}$.}

Figs. 1-3, 8-12

Morphological description. In the light microscope, shape of spores very simple, both in side and apical views; length $5.4(5.3-5.5) \mu \mathrm{m}$, width $5.9(5.8-6.0) \mu \mathrm{m}$, and thickness $6.0(5.9-6.1) \mu \mathrm{m}(\mathrm{n}=20)$. In side view, spores rounded posteriorly and slightly pointed in anterior part. Average length of pyriform polar capsules $2.7 \mu \mathrm{m}$. Spores in apical view basically quadrate with slightly rounded corners and slightly indicated suture line incisions. Coils of polar filament not seen in fresh spores. Plasmodia polysporic, of spindle-shaped form consistent with shape of muscle fibres, their length and width depending on stage of development.

In the transmission electron microscope, inornate type of spores confirmed (Figs. 8, 9). Spores with four shell valves overlapping at suture lines (Fig. 9). Apical part of spore with thickened shell brims (Figs. 8, 12), polar capsules with two turns of polar filament (Fig. 10), sporoplasm in cell-in-cell arrangement (Fig. 8). Capsulogenic cells with electron-dense material of nuclei (Figs. 9, 10). Fibrilar structures connected with spore valves (Fig. 9, arrows) and between two polar capsules (Fig. 11) were observed. Only mature spores were observed within plasmodia and foci of dystrophic muscle tissue. Periphery of plasmodium delimited against host sarcoplasm by thin wall (Fig. 13). As part of muscular disorders, aggregates of host mitochondria with ultrastructural changes were observed (Fig. 14).

Sequence data and phylogenetic analysis. Sequences generated in this study were deposited in GenBank under accession numbers FJ790311 (SSU rDNA) and FJ790312 (LSU rDNA). A marginal difference consisting

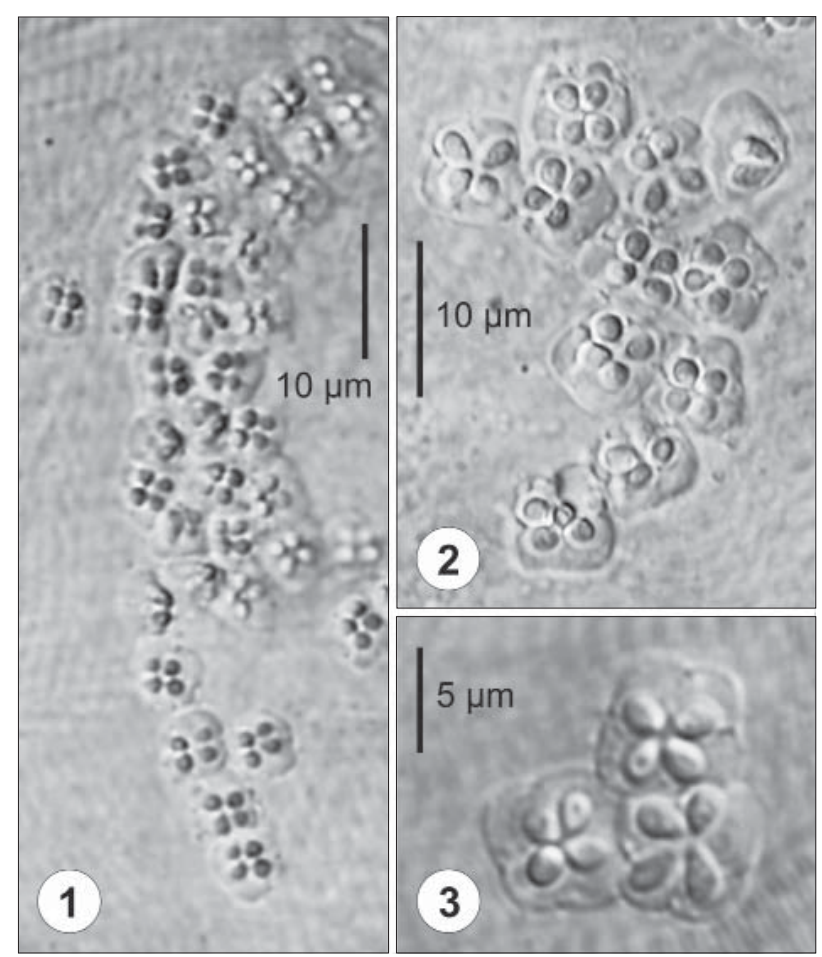

Figs. 1-3. Fresh spores of Kudoa inornata sp. n. as seen in squash preparations from muscle tissue of spotted seatrout $C y$ noscion nebulosus. Nomarski differential interference contrast.

in one substitution per approximately one thousand base pairs was found among the gene sequences generated from three samples of DNA extracted from three seatrout caught in locality 5 (ACE basin). Sequences for final analyses and deposition in GenBank were selected arbitrarily. Based on both molecular markers (SSU and LSU rDNA), K. inornata was found distinct from the hitherto described species with rDNA sequences available in GenBank. Phylogenetic analyses of SSU, LSU, and combined SSU+LSU rDNA sequences revealed a stable sister relationship of K. inornata with K. paniformis (Fig. 15 and supplementary data). In combined analysis, the nodal support for subclade of the latter species (Fig. 15) was moderate $(\mathrm{BI}=0.90, \mathrm{ML}=66 \%$ and $\mathrm{MP}=78 \%)$. The sequence similarity of K. inornata and K. paniformis was $97.88 \%$ when calculated from almost complete SSU rDNA, and $89.83 \%$ when calculated from partial LSU rDNA (about 700 nt of 5' end). In both, SSU and SSU+LSU rDNA based analyses, the sequences of $K$. inornata and $K$. paniformis clustered together with sequences of $K$. dianae, $K$. miniauriculata, Kudoa sp. CMW2003, K. funduli, K. clupeidae, K. alliaria, K. rosenbuschi and Kudoa sp. MMAG5. Bayesian posterior probabilities and bootstraps calculated for this clade were low (BI $=0.61, \mathrm{ML}$ and MP less than $50 \%)$. Phylogenetic analysis of Kudoa spp. based on the limited number of LSU rDNA sequences available to date revealed a different topology of tree (see supplementary data at http://www.mujweb.cz/www/fialaivan/Supplementary.htm). 

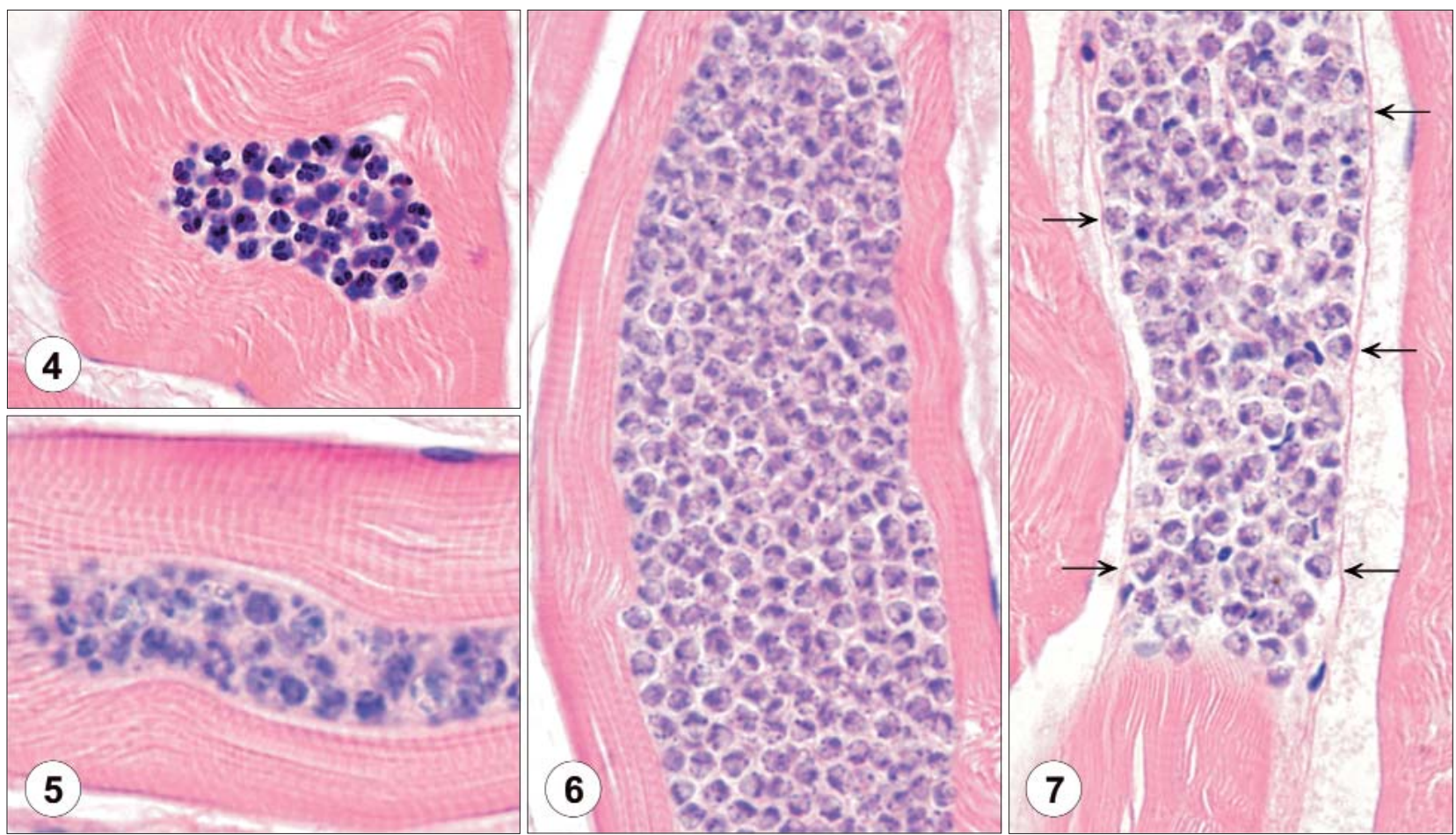

Figs. 4-7. Skeletal muscles of spotted seatrout Cynoscion nebulosus containing advanced plasmodia of Kudoa inornata sp. n. Fig. 4. Transverse section through muscle fibre with plasmodium of K. inornata. Giemsa $\times 740$. Fig. 5. Plasmodium, the shape of which follows the long axis of muscle fibre. $\mathrm{HE} \times 1000$. Fig. 6. Advanced plasmodium containing almost exclusively mature spores that is enveloped by a thin layer of sarcolemma. HE $\times 760$. Fig. 7. Sarcoplasm in a long segment of muscle fibre substituted with mature spores. Sarcolemma marked with arrows. HE $\times 760$.

\section{Taxonomic summary}

Type host: Cynoscion nebulosus (Cuvier, 1830) (Perciformes: Sciaenidae).

Type locality: Ashepoo-Combahee-Edisto (ACE) basin $\left(32^{\circ} 30^{\prime} 0^{\prime \prime} \mathrm{N}, 80^{\circ} 26^{\prime} 18^{\prime \prime} \mathrm{W}\right)$.

Other localities: See in Results.

Site of infection: Skeletal muscles.

Prevale n c e : $100 \%$ in the type locality ( 8 fish positive/ 8 examined).

Type material: Phototypes and histological sections deposited in the Institute of Parasitology, Biology Centre AS CR, České Budějovice. SSU rDNA sequence deposited in GenBank under Acc. No. FJ790311 and LSU rDNA sequence deposited under Acc. No. FJ790312.

E t y m o logy: The specific name relates to the simple-shaped, inornate spores.

\section{DISCUSSION}

The research of Kudoa species has been motivated by a number of reasons. Traditional interest of scientists in morphological diversity of parasites along with the more recent interest in relatedness among species through the use of molecular markers is augmented by concerns about the quality of fish meat.

In the past decades, special attention was paid to the impact of Kudoa infections on the commercially impor- tant Pacific hake (Merluccius productus) and Atlantic salmon (Salmo salar), for which the market value was compromised by $K$. paniformis and $K$. thyrsites infections, respectively (Kudo et al. 1987, Moran and Kent 1999, Moran et al. 1999, Zhou and Li-Chan 2009). In contrast, less effort has been concentrated on other Kudoa infections and other fish hosts, even those of commercial or recreational importance. Characterization of any species, irrespective of the importance of its host, is, however, of interest and potential value to fisheries since some Kudoa species are considered habitat- rather than host specific (Whipps et al. 2003, Whipps and Kent 2006, Burger et al. 2008). The increasing consumption of fish throughout the world (promoted either for health reasons or because it is an affordable source of proteins), and also the recently discovered potential health risk for humans (Martinez de Velasco et al. 2008) are additional reasons to characterize Kudoa species.

In the representatives of Kudoa species with inornate, simple-shaped spores that are difficult to distinguish, molecular characterisation is particularly relevant. This is the case of Kudoa inornata, the spores of which resemble those of unidentified Kudoa spp. from Gulf of Mexico fishes such as Cyprinodon variegatus, Gambusia affinis and Menidia beryllina (Dyková et al. 1994). Unfortunately, molecular data are not available for these Kudoa species, the hosts of which are sympatric with Cynoscion 

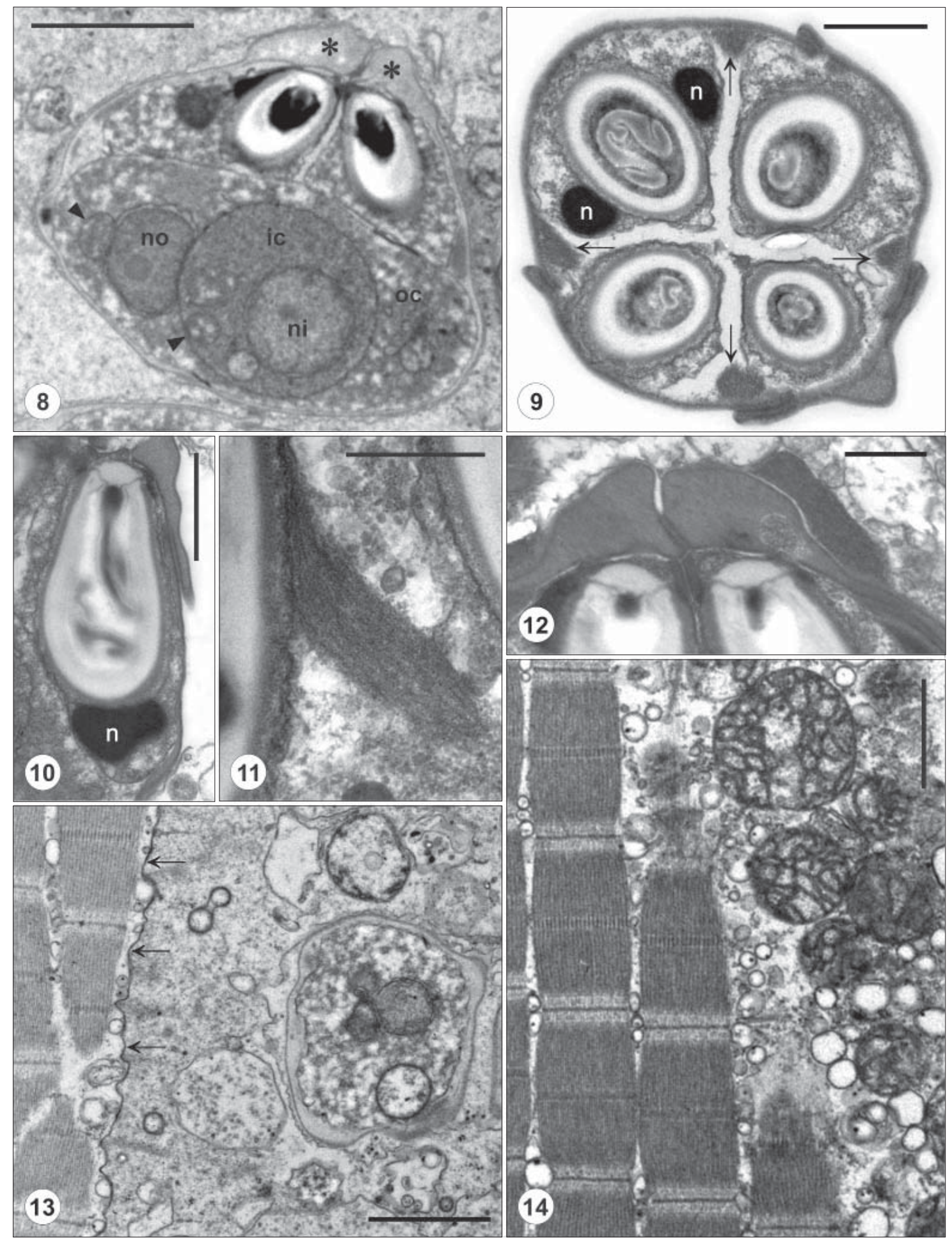

Figs. 8-14. Kudoa inornata sp. n., ultrastructure of spores and infected host tissue. Fig. 8. Mature spore in side view with slightly thickened shell valves in their apical part $(*)$, two polar capsules visible, and cell-in-cell organized sporoplasm (cytoplasm of outer cell $=$ oc, nucleus of outer cell $=$ no, cytoplasm of inner cell $=\mathrm{ic}$, nucleus of inner cell $=$ ni, mitochondria marked with arrowheads). Fig. 9. Mature spore in apical view with overlapping shell valves, four symmetrically localised fibrilar structures (arrows) adjoining to valves on the periphery, four polar capsules, including one with electron-dense nuclei of capsulogenic cells (n). Fig. 10. Polar capsule of mature spore with two turns of polar filament and electron-dense nucleus (n) of capsulogenic cell at the basal part of polar capsule. Fig. 11. Bundle of fibrils between two polar capsules, most probably part of one fibrilar structure marked with arrow in Fig. 9. Fig. 12. Apical part of spore in side view. Fig. 13. Host-parasite interface with remnant of thin plasmodial wall (arrows). Fig. 14. Damage of muscle tissue with a host mitochondrial abnormality involved in the process. Scale bars: Fig. $8=2 \mu \mathrm{m}$; Figs. 9, $10=1 \mu \mathrm{m}$; Figs. 11, $12=500 \mathrm{~nm}$; Figs. 13, $14=200 \mathrm{~nm}$. 


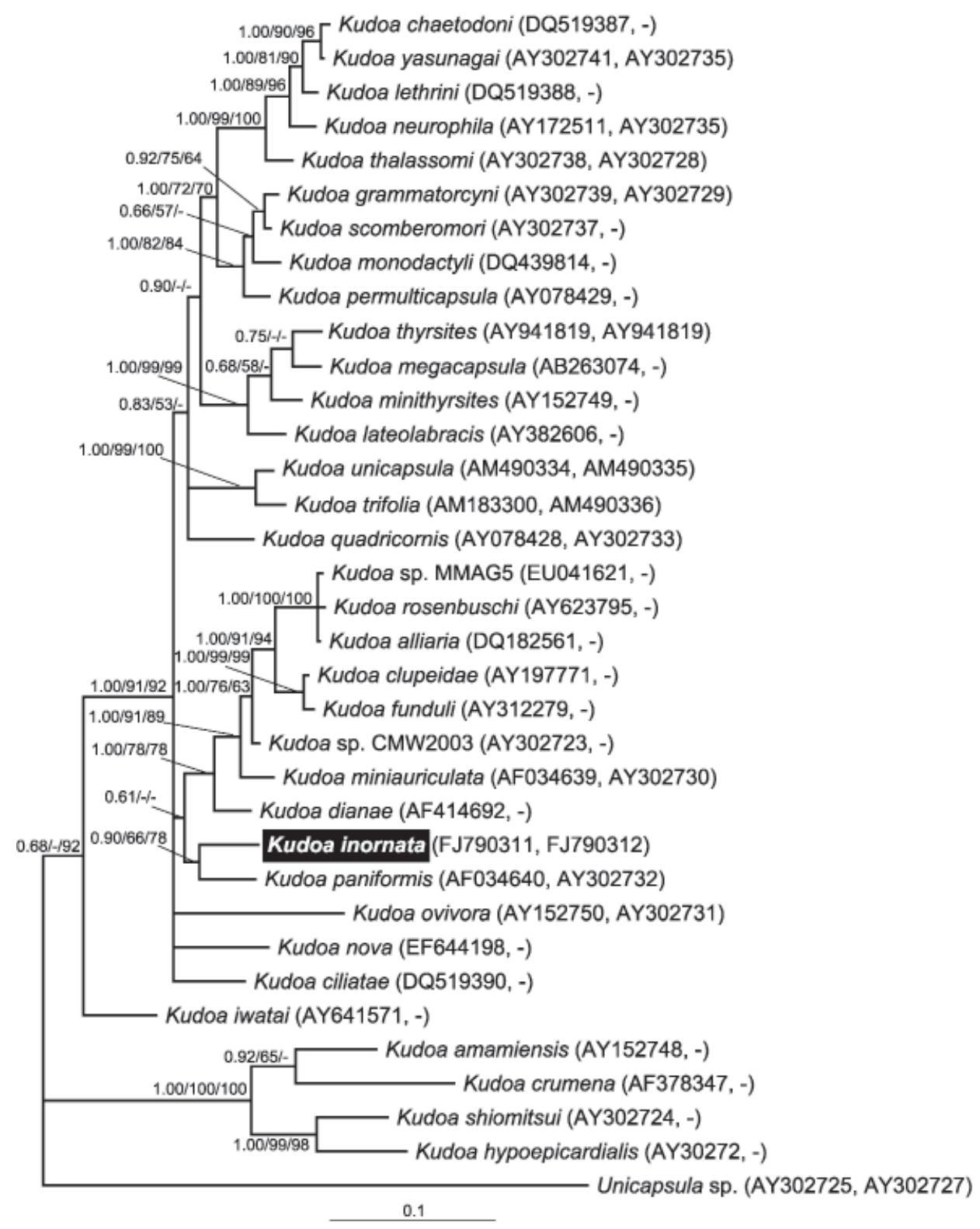

Fig. 15. Bayesian consensus phylogram based on analysis of combined SSU rDNA and LSU rDNA data. Unicapsula was set as outgroup. Nodal support is indicated for BI (posterior probabilities), ML and MP (only bootstrap values greater than $50 \%$ are shown). Species names are supplemented with corresponding GenBank accession numbers for SSU rDNA and LSU rDNA (if the latter were available). All branches are drawn to scale. The number of changes per site is given by scale bar.

nebulosus. To the best of our knowledge, neither morphological nor molecular data are available on the Kudoa sp. reported from Cynoscion arenarius (Overstreet 1983). Thirty nine specimens of the latter fish species previously studied by Dyková et al. (1994) in the Gulf of Mexico were all Kudoa negative.

Comparison of known morphological data of the species phylogenetically most closely related to K. inornata revealed that Kudoa paniformis Kabata et Whitaker, 1981 described from the Pacific whiting, Merluccius productus, also has simple-shaped spores, the size of which does not differ substantially from those of $K$. inornata spores. The vast difference found in sequence similarity calculated for SSU and LSU rDNA markers of both species can be explained by the presence of two long variable regions in the 5' end of LSU rDNA. The same phenomenon, i.e., a more pronounced variability of LSU rDNA sequences, was recognized by Whipps et al. (2004) for 10 multivalvulid species.

Detrimental effect on the host, known as post-mortem myoliquefaction in K. paniformis infections (Patashnik et al. 1982, Stehr 1986, Stehr and Whitaker 1986, Kudo et al. 1987) has not yet been described in spotted seatrout. Nevertheless, a similar effect of $K$. inornata might help 
explain the complaints of recreational fishers in South Carolina that spotted seatrout flesh becomes soft and mushy if not consumed promptly after the fish is caught.

The group of species that in our analysis formed a sister subclade to K. inornata and K. paniformis consisted of those that were treated in detail by Whipps and Diggles (2006). Most of them infect fish in the Western Atlantic. In addition to minute spore differences, these authors also characterized host specificity of individual myxosporean species and pointed out studies containing misidentifications. Compared to a more recent paper on the patterns of relatedness in the Kudoidae (Burger et al. 2007), our study revealed a different phylogenetic position of $K$. paniformis, however, the bootstrap support remained low. In addition, our analysis resolved positions of sequences representing Kudoa spores from Macruronus magellanicus (EU041621) and Paralichthys lethostigma (AY302723). Although these spores were not characterized morphologically, our phylogenetic analyses clarified that spores from the Southern flounder (P. lethostigma), which is sympatric with C. nebulosus in estuaries and coastal waters of South Carolina, do not belong to K. inornata.

In conclusion, morphological and molecular characterisation of $K$. inornata and the assessment of its pathogenic potential for C. nebulosus contributed to the knowledge of an important group of myxosporeans. Further investigations that will involve a study of this species' life cycle, determination of host specificity and the extent of its deleterious effect on its host are deemed necessary to understand its impact on South Carolina estuaries and economy.

Acknowledgements. Financial support was provided by the Ministry of Education, Youth and Sports of the Czech Republic (MSM 6007665801) and research projects of the Institute of Parasitology, Biology Centre of the Academy of Sciences of the Czech Republic (Z60220518 and LC522). The authors wish to thank the Fulbright Program for supporting this research and the College of Charleston for granting sabbatical leave to Isaure de Buron.

\section{REFERENCES}

Akaishi F., Easy R., St-Jean S., Courtenay S., de Oliveira Ribeiro C.A., Cone D. 2004: Supplemental diagnosis of Kudoa funduli (Myxozoa) parasitizing Fundulus heteroclitus (Cyprinodontidae) from Coastal North eastern North America. J. Parasitol. 90: 477-480.

Barta J.R., Martin D.S., Liberator P.A., Dashkewitz M., Anderson J.W., Deighner S.D., Elbrecht A.,Perkins-Barrow A., Jenkins M.C., Danforth H.D., Ruff M.D., ProfousJuchelka H. 1997: Phylogenetic relationships among eight Eimeria species infecting domestic fowl inferred using complete small subunit ribosomal DNA sequences. J. Parasitol. 83: 262-271.

Bartošoví P., Fiala I., Hypša V.: Concatenated SSU and LSU rDNA data confirm the main evolutionary trends within myxosporeans (Myxozoa: Myxosporea) and provide effective tool for their molecular phylogenetics. Mol. Phylogenet. Evol. (In press.)

Berger T.L. (Ed.) 2008: 66th Annual Report of the Atlantic States Marine Fisheries Commission 2007, 66 pp.

Blaylock R.B., Bullard S.A., Whipps C. 2004: Kudoa hypoepicardialis n.sp. (Myxozoa: Kudoidae) and associated lesions from the heart of seven perciform fishes in the Northern Gulf of Mexico. J. Parasitol. 90: 584-593.

Blaylock R.B., Overstreet R.M. 2003: Diseases and parasites of the spotted trout. In: S.A. Bortone (Ed.), Biology of the Spotted Seatrout. CRC, Boca Raton, pp. 197-225.

Bortone S.A.(Ed.) 2003: Biology of the Spotted Seatrout. CRC Press, Boca Raton, FL, 328 pp.

Bunton T.E., Poynton S.L. 1991: Kudoa sp. (Myxosporea, Multivalvulida) infection in juvenile white perch, Morone americana (Gmelin): histopathology and spore morphology. J. Fish Dis. 14: 589-594.

Burger M.A.A., Barnes A.C., Adlard R.D. 2008: Wildlife as reservoirs for parasites infecting commercial species: host specificity and a redescription of Kudoa amamiensis from teleost fish in Australia. J. Fish Dis. 31: 835-844.

Burger M.A.A., CribB T.H., Adlard R.D. 2007: Patterns of relatedness in the Kudoidae with descriptions of Kudoa chaeto- doni n. sp. and K. lethrini n. sp. (Myxosporea: Multivalvulida). Parasitology 134: 669-681.

Dyková I., Lom J., Overstreet R.M. 1994: Myxosporean parasites of the genus Kudoa Meglitsch, 1947 from some Gulf of Mexico fishes: description of two new species and notes on their ultrastructure. Eur. J. Protistol. 30: 316-323.

HAнN C.W. 1915: Sporozoan parasites of certain fishes in the vicinity of Woods Hole, Mass. Bull. Bur. Fish. 33: 193-214.

HahN C.W. 1917: On the sporozoon parasites of the fishes of Woods Hole and vicinity. III On the Chloromyxum clupeidae of Clupea harengus (Young), Pomolobus pseudoharengus (Young), and P. aestivalis (Young). J. Parasitol. 14: 13-20.

HALL T.A. 1999: BioEdit: a user-friendly biological sequence alignment editor and analysis program for Windows 95/98/NT. Nucl. Acids Symp. Ser. 41: 95-98.

Harris J.R. (Ed.) 1991: Electron Microscopy in Biology. A Practical Approach. Oxford University Press, New York, 308 pp.

Iversen E.S., van Meter N.N. 1967: A new myxosporidian (Sporozoa) infecting the Spanish mackerel. Bull. Mar. Sci. 17: 268273.

James J.T., Stunz G.W., McKee D.A., Vega R.R. 2007: Catchand-release mortality of spotted seatrout in Texas: effects of tournaments, seasonality and anatomical hooking location. N. Am. J. Fish. Manag. 27: 900-907.

Joy J.E. 1972: A new species of Kudoa (Myxosporidea: Chloromyxidae) from the spot, Leiostomus xanthurus Lacépède in Clear Lake, Texas. J. Protozool. 19: 264-265.

Kent M.L., Andree K.B., Bartholomew J.L., El-Matbouli M., Desser S.S., Devllin R.H., Feist S.W., Hedrick R.P., Hoffmann R.W., Khattra J., Hallett S.L., Lester R.J.G., Longshaw M., Palenzuela O., Siddall M.E., Xiao C. 2001: Recent advances in our knowledge of the Myxozoa. J. Eukaryot. Microbiol. 48: 395-413.

Kudo G., Barnett H.J., Nelson R.W. 1987: Factors affecting cooked texture quality of Pacific whiting, Merluccius productus, fillets with particular emphasis on the effect of infection by the myxosporeans Kudoa paniformis and K. thyrsites. Fish. Bull. 85: $745-755$. 
Lom J., Arthur J.R. 1989: A guideline for the preparation of species description in Myxosporea. J. Fish Dis. 12: 151-156.

Martinez de Velasco G., Rodero M., Cuéllar C., Chivato T., Mateos J.M., Laguna R. 2008: Skin prick test of Kudoa sp. antigens in patients with gastrointestinal and/or allergic symptoms related to fish ingestion. Parasitol. Res. 103: 713-715.

Meglitsch P.A. 1947: Studies on Myxosporidia of the Beaufort region II. Observation on Kudoa clupeidae (Hahn) gen. nov. J. Parasitol. 33: 271-277.

Meglitsch P.A. 1948: On Kudoa funduli (Hahn). Trans. Am. Microsc. Soc. 67: 272-274.

Moran J.D.W., Kent M.L. 1999: Kudoa thyrsites (Myxozoa: Myxosporea) infections in pen-reared Atlantic salmon in the eastern North Pacific Ocean, with a survey of potential nonsalmonid reservoir hosts. J. Aquat. Anim. Health 11: 101-109.

Moran J.D.W., Whitaker D.J., Kent M.L. 1999: A review of the myxosporean genus Kudoa Meglitsch, 1947, and its impact on the international aquaculture industry and commercial fisheries. Aquaculture 172: 163-196.

Nigrelli R. 1946: Parasites and diseases of the ocean pout, Macrozoarces americanus (Bloch and Schneider). Bull. Bing. Oceanogr. Coll. 9: 187-221.

Oliva M., Luque J.L., Terán L., Llicán L. 1992: Kudoa sciaenae (Myxozoa: Multivalvulidae) cysts distribution in the somatic muscles of Stellifer minor (Tschudi, 1844) (Pisces: Sciaenidae). Mem. Inst. Oswaldo Cruz 87: 33-35.

Overstreet R.M. 1978: Marine maladies? Worms, germs, and other symbionts from the northern Gulf of Mexico. MississippiAlabama Sea Grant Consortium, MASGP-78-021. Blossman Printing, Ocean Springs, Mississippi, 140 pp.

Overstreet R.M. 1983: Aspect of the biology of the spotted seatrout Cynoscion nebulosus in Mississippi. Gulf Res. Rep. (Suppl. 1): 1-43.

Paperna I., Zwerner D.E. 1974: Kudoa cerebralis sp. n. (Myxosporidea, Chloromyxidae) from the striped bass, Morone saxatilis (Walbaum). J. Protozool. 21: 15-19.

Patashnik M., Groninger H.S., Barnett H., Kudo G., Koury B. 1982: Pacific whiting, Merluccius productus: I. Abnormal muscle texture caused by myxosporidian-induced proteolysis. Mar. Fish Rev. 44: 1-12.

Posada D., Crandall K.A. 1998: Modeltest: testing the model of DNA substitution. Bioinformatics 14: 817-818.

Reimschuessel R., Gieseker C.M., Driscoll C., Baya A., Kane A.S., Blazer V.S., Evans J.J., Kent M.L., Moran J.D.W., Poynton S.L. 2003: Myxosporean plasmodial infection associ- ated with ulcerative lesions in young-of-the-year Atlantic menhaden in a tributary of the Chesapeake Bay, and possible links to Kudoa clupeidae. Dis. Aquat. Org. 53: 143-166.

Ronquist F., Huelsenbeck J.P. 2003: MrBayes 3: Bayesian phylogenetic inference under mixed models. Bioinformatics 19: 1572-1574.

SteHR C. 1986: Sporogenesis of the myxosporean Kudoa paniformis Kabata et Whitaker, 1981 infecting the muscle of the Pacific whiting, Merluccius productus (Ayres). J. Fish Dis. 9: 493-504.

Stehr C., Whitaker D.J. 1986: Host-parasite interaction of the myxosporeans Kudoa paniformis Kabata et Whitaker, 1981 and Kudoa thyrsites (Gilchrist, 1924) in the muscle of Pacific whiting, Merluccius productus (Ayres): an ultrastructural study. J. Fish Dis. 9: 505-517.

Swofford D.L. 2001: PAUP*: Phylogenetic Analysis Using Parsimony, Version 4.0b10. Sinauer Associates, Sunderland, MA.

Thompson J.D., Gibson T.J., Plewniak F., Jeanmougin F., HigGINS D.G. 1997: The CLUSTAL_X windows interface: flexible strategies for multiple sequence alignment aided by quality analysis tools. Nucl. Acids Res. 25: 4876-4882.

Webb S.R., Garman G.C., McIninch S.P., Nerad T.A., Peglar M.T., Gillevet P.M., Brown B.L. 2005: Etiology of ulcerative lesions of Atlantic menhaden (Brevoortia tyrannus) from James River, Virginia. Parasitol. Res. 97: 358-366.

Whipps C.M., Adlard R.D., Bryant M.S., Kent M.L. 2003: Two unusual myxozoans, Kudoa quadricornis n. sp. (Multivalvulida) from the muscle of goldspotted trevally (Carangoides fulvoguttatus) and Kudoa permulticapsula n. sp. (Multivalvulida) from the muscle of Spanish mackerel (Scomberomorus commersoni) from the Great Barrier Reef, Australia. J. Parasitol. 89: 168-173.

Whipps C.M., Diggles B.K. 2006: Kudoa alliaria in flesh of Argentinian Hoki Macruronus magellanicus (Gadiformes; Merlucciidae). Dis. Aquat. Org. 69: 259-263.

Whipps C.M., Grossel G., Adlard R.D., Yokoyama H., Bryant M.S., Munday B.L., Kent M.L. 2004: Phylogeny of the Multivalvulidae (Myxozoa: Myxosporea) based on comparative ribosomal DNA sequence analysis. J. Parasitol. 90: 618-622.

Whipps C.M., Kent L.M. 2006: Phylogeography of the cosmopolitan marine parasite Kudoa thyrsites (Myxozoa: Myxosporea). J. Eukaryot. Microbiol. 53: 364-373.

Zhou L.S., Li-Chan E.C.Y. 2009: Effects of Kudoa spores, endogenous protease activity and frozen storage on cooked texture of minced Pacific hake (Merluccius productus). Food Chem. 113: 1076-1082. 